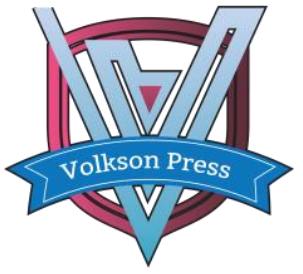

\title{
Optimal Capital Structure and Corporate Performance:The Case of Information Technology Industrial Companies in China
}

Jiahui Wu

Nanjing University of Science and Technology Nanjing, China

*312491008@qq.com

This is an open access article distributed under the Creative Commons Attribution License, which permits unrestricted use, distribution, and reproduction in any medium, provided the original work is properly cited.

\section{ARTICLE DETAILS}

\section{Article History:}

\section{Received 02 october 2017}

Accepted 06 october 2017

Available online 11 october 2017

\section{Keywords:}

Capital structure; Corporate

performance; Information

technology industry.

\section{ABSTRACT}

To research the optimal capital structure for corporate performance of information technology industry, the paper used three aspects to represent the capital structure, chose the information technology companies as samples, and constructed a quadratic function model to verify the relevant assumptions. The results state that Chinese companies in information technology industry have the optimal asset-liability ratio, the current liabilities ratio affects the their performance negatively, the concentration of ownership has an positive effect on the corporate performance, therefore companies should consider the mixture of equity and debt. The results will be used to research the optimal capital structure in other industries and countries.

\section{Introduction}

The study of capital structure theory can be traced back to the MM theory in 1958, which did not take into account the tax. Then scholars began to add a variety of factors, considering the value of debt and equity from different angles. They put forward the theory of agency cost, signal transmission and trade-off and believe that the composition of different equities and liabilities of enterprises will affect the performance, and the performance of any company hinges around its ability to operate on a capital structure (Bandyopadhyay A,2016) [1].With the development of social technology, the information technology industry is developing rapidly, which plays an important role in promoting economic prosperity. At present, most studies on the relationship between capital structure and corporate performance take the gem or small board listed companies as the background, or in large industries, such as manufacturing and real estate industry as an example, but less researchers analyze the information technology industry. Therefore, this paper is going to research the relationship between capital structure and company's performance based on information technology industry is of great significance.

\section{Theoretical analysis and assumptions}

\subsection{The impact of financing structure on corporate performance}

Comparing with the issuance of shares or raising funds directly from shareholders, the debt will bring tax shield benefits, interest costs reduce corporate profits, therefore contributing to reducing corporate taxes, which amplifies the changes in EBIT effect, thereby increasing shareholder confidence, bringing a good signal, expanding the scale of corporate development, increasing investment opportunities, improving economic efficiency. But the debt also produces the cost, companies are therefore facing debt pressure, while increasing the risk of corporate bankruptcy.Trade-off theory says that when the marginal tax shield income is greater than the cost of bankruptcy, increasing the debt is conducive to business performance increase, but when the debt increases to a certain extent, the corresponding bankruptcy costs will increase, and the tax shield income will be relatively reduced, when the bankrupt cost is equal to the tax shield income of marginal debt, the corporate value reaches the top point. Xiong J(2014) used the double threshold model to verify the non-linear relationship between leverage and corporate performance and found the non-linear relationship between them [2].Therefore, debt financing should take into account the benefits and costs of liabilities, and firms should consider the mixture of equity and debt since they are major determinants of corporate performance (Kakanda M M,2016) [3], then choose the optimal asset-liability ratio. Based on the above analysis, this paper proposes:

H1:The corporate asset-liability ratio has the reverted U-shaped relationship with corporate performance.

\subsection{The impact of debt structure on corporate performance}

Compared to short-term debt, the debt pressure of long-term debt are less. Due to the longer period, the company does not have to repay the longterm debt in the short term. The longer preparation period is more conducive to the stability of cash flow.In addition, although short-term liabilities bring lower interest rates, but because of the short repayment period, the company needs to continue to borrow in order to maintain long-term business, which will bring refinancing cost, and rolling financing cost will increase, in addition, rollover risk implied by short-term funding adds to the cost of long-term debt (Klimenko N,2015) [4], the use of excessive short-term debt to maintain the normal operation of the corporation will bring credit and liquidity risk, so the overall cost of capital in different current liabilities may be different, thus affecting the corporate performance. Based on the above analysis, this paper proposes:

H2: The current liabilities ratio is negatively related to the corporate performance.

\subsection{The impact of the equity structure on the corporate performance}

When the shares are highly dispersed, the different shareholding ratios bring different benefits, and for shareholders with the relative small proportion, spending the same cost as the major shareholders to supervise the manager is not worth, so the highly dispersed equity also means that shareholders need to spend more time, and more energy to make a consensus, this result will lead to governance costs more than the profits, which is not conducive to effective management of corporations. And the benefits assigned to the major shareholders are far greater than their supervision costs, so they have more impetuses to manage managers, giving full play to their functions, reducing managers' personal profit behaviors, and more easily through the shareholders to reach a consensus, thereby improving corporate performance. And Hastori H (2015) investigated determinants of agency costs, found that ownership concentration affected agency costs in vary [5] 
H3:The proportion of the top ten shareholders is positively related to the corporate performance.

\section{Sample selection and research design}

\subsection{Sample selection and data source}

The samples are about Chinese information technology companies listed on the Shanghai and Shenzhen A Stock Exchange from 2013 to 2015, the data are from the Cathay Pacific database, a total of 582 samples were obtained.

\subsection{Variable selection}

\subsubsection{Company performance evaluation index}

This paper uses the factor analysis to measure the corporate performance.

\section{Table 1 Business performance indicators}

\begin{tabular}{|c|c|c|}
\hline Indicator type & $\begin{array}{l}\text { Indicator } \\
\text { definitions }\end{array}$ & Indicator description \\
\hline \multirow{5}{*}{ Profitability } & $\begin{array}{ll}\begin{array}{l}\text { Return } \\
\text { assets }\end{array} & \text { on } \\
\end{array}$ & $\begin{array}{l}\text { (Total profit }+ \text { financial expenses) } / \\
\text { average total assets }\end{array}$ \\
\hline & $\begin{array}{ll}\begin{array}{l}\text { Return } \\
\text { equity }\end{array} & \text { on } \\
\end{array}$ & $\begin{array}{lll}\begin{array}{l}\text { Net profit / average balance of } \\
\text { shareholders' equity }\end{array} & \\
\end{array}$ \\
\hline & Table1 $\cdot$ Con & \\
\hline & $\begin{array}{l}\text { Operating } \\
\text { margin }\end{array}$ & Operating profit / operating income \\
\hline & $\begin{array}{l}\text { Operating net } \\
\text { profit margin }\end{array}$ & Net profit / operating income \\
\hline \multirow{2}{*}{$\begin{array}{l}\text { Operating } \\
\text { ability }\end{array}$} & $\begin{array}{l}\text { Receivables } \\
\text { turnover }\end{array}$ & $\begin{array}{l}\text { Operating income / receivables average } \\
\text { occupancy }\end{array}$ \\
\hline & $\begin{array}{l}\text { Inventory } \\
\text { turnover }\end{array}$ & $\begin{array}{l}\begin{array}{l}\text { Operating cost / inventory average } \\
\text { occupancy }\end{array} \\
\end{array}$ \\
\hline \multirow{3}{*}{$\begin{array}{l}\text { debt-paying } \\
\text { ability }\end{array}$} & current ratio & Current assets / current liabilities \\
\hline & Quick ratio & $\begin{array}{l}\text { (Current assets - inventory) / current } \\
\text { liabilities }\end{array}$ \\
\hline & $\begin{array}{l}\text { Interest } \\
\text { expense } \\
\text { multiplier }\end{array}$ & EBIT / interest expenses \\
\hline \multirow[t]{2}{*}{$\begin{array}{l}\text { Development } \\
\text { ability }\end{array}$} & $\begin{array}{l}\text { Total profit } \\
\text { growth rate }\end{array}$ & $\begin{array}{l}\text { Total profit for the current period - total } \\
\text { profit for the previous period) / total profit } \\
\text { for the previous period }\end{array}$ \\
\hline & $\begin{array}{l}\text { Basic earnings } \\
\text { per share }\end{array}$ & $\begin{array}{l}\text { (Basic earnings per share for the current } \\
\text { period - Basic earnings per share for the } \\
\text { previous period) / Basic earnings per share } \\
\text { for the current period }\end{array}$ \\
\hline
\end{tabular}

Table 2 Various variables and instructions

\begin{tabular}{|l|l|l|l|}
\hline Variable type & $\begin{array}{l}\text { Variable } \\
\text { name }\end{array}$ & $\begin{array}{l}\text { Variable } \\
\text { definitions }\end{array}$ & Variable description \\
\hline $\begin{array}{l}\text { dependent } \\
\text { variable }\end{array}$ & PER & $\begin{array}{l}\text { Corporate } \\
\text { Performance }\end{array}$ & $\begin{array}{l}\text { Measured by the factor } \\
\text { analysis }\end{array}$ \\
\hline \multirow{3}{*}{$\begin{array}{l}\text { Independent } \\
\text { variable }\end{array}$} & LEV & $\begin{array}{l}\text { Total asset - } \\
\text { liability ratio }\end{array}$ & $\begin{array}{l}\text { Average total liabilities / } \\
\text { average total assets }\end{array}$ \\
\cline { 2 - 4 } & CDR & $\begin{array}{l}\text { Current debt } \\
\text { ratio }\end{array}$ & $\begin{array}{l}\text { Ending current liabilities / } \\
\text { ending total liabilities }\end{array}$ \\
\cline { 2 - 4 } Control & $\begin{array}{l}\text { Top } \\
\text { shareholding }\end{array}$ & $\begin{array}{l}\text { Number of shares held by } \\
\text { top 10 shareholders /total } \\
\text { number of shares }\end{array}$ \\
\hline & FAR & Fixed asset ratio & $\begin{array}{l}\text { Ending fixed assets / ending } \\
\text { total assets }\end{array}$ \\
\cline { 2 - 4 } & SIZE & Company size & $\begin{array}{l}\text { The logarithm of ending } \\
\text { total assets }\end{array}$ \\
\cline { 2 - 4 } & MSR & $\begin{array}{l}\text { Executive } \\
\text { shareholding } \\
\text { ratio }\end{array}$ & $\begin{array}{l}\text { Number of shares held by } \\
\text { executive shareholders / } \\
\text { total number of shares }\end{array}$ \\
\hline
\end{tabular}

\subsubsection{Model}

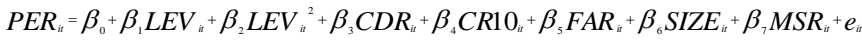
Where $\beta_{1} \sim \beta_{7}$ are the regression coefficients, $e$ is the residual.

\section{Empirical results and analysis}

\subsection{An analysis of the current situation of capital structure}

Table 3 Descriptive statistics of capital structure indicators

\begin{tabular}{|l|l|l|l|l|l|}
\hline Indicator & Year & Maximum & Minimum & Mean & $\begin{array}{l}\text { Standard } \\
\text { deviation }\end{array}$ \\
\hline
\end{tabular}

\begin{tabular}{|l|l|l|l|l|l|}
\hline \multirow{4}{*}{ LEV } & 2013 & $78.93 \%$ & $2.39 \%$ & $30.03 \%$ & 0.183 \\
\cline { 2 - 6 } & 2014 & $77.85 \%$ & $2.43 \%$ & $31.13 \%$ & 0.182 \\
\cline { 2 - 6 } & 2015 & $78.58 \%$ & $2.71 \%$ & $32.39 \%$ & 0.180 \\
\hline \multirow{3}{*}{ CDR } & 2013 & $100 \%$ & $22.35 \%$ & $90.66 \%$ & 0.126 \\
\cline { 2 - 6 } & 2014 & $100 \%$ & $23.49 \%$ & $89.70 \%$ & 0.128 \\
\cline { 2 - 6 } & 2015 & $100 \%$ & $26.23 \%$ & $88.03 \%$ & 0.135 \\
\hline \multirow{3}{*}{ CR10 } & 2013 & $88.81 \%$ & $14.03 \%$ & $58.41 \%$ & 3.104 \\
\cline { 2 - 6 } & 2014 & $99.63 \%$ & $13.92 \%$ & $58.42 \%$ & 2.314 \\
\cline { 2 - 6 } & 2015 & $99.00 \%$ & $14.00 \%$ & $56.72 \%$ & 0.148 \\
\hline
\end{tabular}

The average asset-liability ratio in China's information technology industry is about $31 \%$, which indicates that the industry prefers equity financing, the proportion of debt financing is relatively low. Although the current liabilities are declining, but the three-year averages are all more than $85 \%$, the sample companies are inclined to short-term financing. The average proportion of the top ten shareholders is more than $50 \%$, which means that more than half of the company's voting rights are in the hands of few shareholders, the equity is more concentrated.

\subsection{Analysis of regression results}

\section{Table 4 The regression results}

\begin{tabular}{|c|c|c|c|c|c|c|}
\hline \multirow[b]{2}{*}{ Variable } & \multirow[b]{2}{*}{ Coefficien } & \multirow[b]{2}{*}{ standard error } & \multirow[b]{2}{*}{ T value } & \multirow[b]{2}{*}{ P value } & \multicolumn{2}{|c|}{ Collinearity statistics } \\
\hline & & & & & Tolerance & VIF \\
\hline C & 0.4435 & 0.5335 & 0.8313 & 0.4064 & - & - \\
\hline LEV & $-4.8132^{* * *}$ & 0.4059 & -11.8588 & 0.0000 & 0.655 & 1.526 \\
\hline $\mathrm{LEV}^{\wedge} 2$ & $4.6252^{* * *}$ & 0.5562 & 8.3157 & 0.0000 & E & \\
\hline CDR & $-0.3440^{* *}$ & 0.1450 & -2.3722 & 0.0182 & 0.926 & 1.079 \\
\hline CR10 & $0.0002^{* *}$ & 0.0020 & 2.0503 & 0.0409 & 0.943 & 1.061 \\
\hline FAR & $-0.4717^{* * *}$ & 0.1673 & -2.8194 & 0.0051 & 0.912 & 1.097 \\
\hline SIZE & $0.0396^{*}$ & 0.0233 & 1.6994 & 0.0901 & 0.605 & 1.653 \\
\hline MSR & $-0.0564^{* * *}$ & 0.0228 & -3.3213 & 0.0010 & 0.363 & 2.755 \\
\hline $\begin{array}{l}\text { R-square } \\
\text { F-statisti } \\
\text { Adjusted }\end{array}$ & $\begin{array}{l}0.536 \\
33.789 \\
\text { squared }\end{array}$ & 523 & & & & \\
\hline
\end{tabular}

The quadratic standard coefficient is negative, indicating that LEV and PER have quadratic function relationship, and the quadratic curve shows inverted U-type, which verifies $\mathrm{H} 1$, and the optimal asset-liability ratio is $51.9 \%$. CDR was negatively correlated with PER, which verifies $\mathrm{H} 2$, indicating that too many short-term liabilities would bring negative effects, which affects the corporate performance. CR10 and PER were positively correlated, verifying the $\mathrm{H} 3$, indicating that the higher the degree of ownership, the greater the relative rights of shareholders, the stronger its execution, thereby improving corporate performance.

\section{Conclusion}

In this paper, we find that the listed companies in China's information technology industry have obvious financing preferences, the proportion of debt financing is generally low, asset-liability ratio and corporate performance have inverted "U" type relationship, and the optimal assetliability ratio is $51.9 \%$, most companies of technology industry should increase their debt proportion. In addition, from the debt structure, the information technology industry listed companies prefer short-term debt financing, the average value fluctuates around $90 \%$ in the past three years, much current liabilities will bring liquidity risk and credit risk, resulting in reduced corporate performance, from the ownership structure, the concentration proportion of shareholders will have a positive effect on the performance, major shareholders will pay more attention to their own interests in the corporate performance, effectively supervising managers, taking timely actions to avoid bad behaviors. Therefore, the greater proportion controlling shareholder has, the more significant effect it does.

\section{Reference}

[1]Bandyopadhyay A, Barua N M. Factors determining capital structure and corporate performance in India: Studying the business cycle effects[]]. Quarterly Review of Economics \& Finance, 2016, 61:160-172. 
[2] Xiong J. Capital structure on the impact of corporate performance research [D]. Jinan University, 2014.

[3]Kakanda M M, Bello A B, Abba M. Effect of Capital Structure on the Performance of Listed Consumer Goods Companies in Nigeria[J]. Social Science Electronic Publishing, 2016.

[4]Klimenko N, Morenobromberg S. Short Term Debt and Bank Liability Structure[J]. Social Science Electronic Publishing, 2015.

[5]Hastori H, Siregar H, Sembel R, et al. Agency Costs, Corporate
Governance and Ownership Concentration: The Case of Agro-industrial Companies in Indonesia[J]. Asian Social Science, 2015, 11(18).

[6] Pu Z F, Xiao Z H.A Study on the Dynamic Interaction between Growth and Profitability of Small and Medium-sized Listed Companies - Based on the Change of Capital Structure [J]. Management World, 2015 (5): 184-185.

[7] LI L. Study on the inverted U-shaped relationship between capital structure and firm value - based on the intermediary effect of corporate risk-taking [J]. Jiangsu Social Sciences, 2016 (3): 109-115.

[8] Tao H X. Capital Structure Fluctuation and Equity Capital Cost [D]. Anhui University of Technology, 2016. 